\title{
Evaluation of an oral health program for children in early childhood
}

\section{Avaliação de um programa de promoção de saúde bucal para crianças da primeira infância}

\begin{abstract}
Purpose: To evaluate an educative and oral health promotion program for children from three public daycare facilities in the city of João Pessoa (PB), in the Northeastern region of Brazil.

Methods: Sample was composed of 219 children who were divided into four age groups: 0 to 12,13 to 24,25 to 36 and 37 to 48 months. All children were submitted to clinical exams and preventive procedures of hygiene and topical application of fluoride at 3-month intervals during 12 months. Mothers were given instructions of oral hygiene of their children. The dmft index and the presence of active white spots (AWS) were recorded.

Results: Mean (SD) values of the initial and final dmft were 0.65 (1.3) and 0.72 (1.5), respectively $(P<0.05)$. The initial and final numbers of AWS were 44 and 08 , respectively. The absence of nocturnal hygiene was associated with AWS for children that received nocturnal breast-feeding. The most relevant variables for dental caries development were: age group, absence of nocturnal oral hygiene and nocturnal breast-feeding; for AWS only the absence of nocturnal oral hygiene was significant $(P<0.05)$.

Conclusion: This oral health program showed to be effective in the maintenance of oral health. The most relevant risk factors for dental caries were absence of nocturnal oral hygiene and nocturnal breast-feeding.
\end{abstract}

Key words: Preventive Dentistry; dental health education; Pediatric Dentistry

\section{Resumo}

Objetivo: Avaliar um programa de educação e promoção de saúde bucal em crianças de três creches públicas da cidade de João Pessoa, PB, Brasil.

Metodologia: A amostra foi constituída de 219 crianças de 0 a 48 meses divididas em quatro grupos etários: 0 a 12; 13 a 24; 25 a 36 e 37 a 48 meses. As crianças foram submetidas a exames clínicos e procedimentos preventivos de higiene bucal e aplicação tópica de flúor em intervalos trimestrais durante 12 meses. As mães das crianças receberam instrução de higiene. Registraram-se os índices de ceo-d e presença de manchas brancas ativas (MBA).

Resultados: As médias (desvio-padrão) do ceo-d inicial e final foram de 0,65 $(1,3)$ e $0,72(1,5)$ respectivamente $(P<0,05)$. O número de MBAs inicial e final foi 44 e 08 , respectivamente. A ausência de higiene noturna foi associada a MBA para crianças que tomavam mamadeira noturna. As variáveis relevantes para o surgimento de cárie foram a faixa etária, ausência de higiene noturna e amamentação noturna; para MBA somente a falta de higiene noturna foi significativa.

Conclusão: O programa mostrou-se eficaz na manutenção da saúde bucal. Os fatores de risco mais relevantes para a cárie dentária foram falta de higiene e amamentação noturna.

Palavras-chave: Odontologia Preventiva; educação em saúde bucal; Odontopediatria

\author{
Maria de Fátima Gabínio de Siqueira ${ }^{\circ}$ \\ Maria Carmen de Araújo M. Jardima \\ Fábio Correia Sampaio b \\ Laurylene César de S. Vasconcelos ${ }^{b}$ \\ Laís César de Vasconcelos ${ }^{c}$
}

- School of Dentistry, Centro Universitário da Paraíba - Unipê, João Pessoa, PB, Brazil

b Department of Clinical and Social Dentistry, Universidade Federal da Paraíba, João Pessoa, PB, Brazil

c Dental School, Universidade Federal da Paraíba, João Pessoa, PB, Brazil

\section{Correspondence:}

Laurylene César de Souza Vasconcelos

Rua Maria Helena da Rocha, 113 - Aeroclube

João Pessoa, PB - Brasil

58036-823

E-mail: laurylene@uol.com.br

Received: June 16, 2010

Accepted: September 29, 2010

Conflict of Interest Statement: The authors state that there are no financial and personal conflicts of interest that could have inappropriately influenced their work.

Copyright: (c) 2010 Siqueira et al.; licensee EDIPUCRS. This is an Open Access article distributed under the terms of the Creative Commons AttributionNoncommercial-No Derivative Works 3.0 Unported License. 


\section{Introduction}

Dental caries is considered to be a public health problem due to its high prevalence and severity, requiring specific policies and actions for prevention. Education and access to information on preventive methods are important factors for dental caries prevention in the community. Regarding educational aspects, the subject is not longer passive to oral health programs but has an active role as a collaborator $(1,2)$.

For children in preschool age, early onset of dental caries may be an important health issue because it affects groups with socioeconomic and nutritional disadvantages, especially children from low income families, as well as ethnic, racial and cultural minorities (3). Despite the overall decline in dental caries rates, mainly observed in children in school ages, reduction of caries in preschoolers is not occurring at the same rate, and caries statistics in this group seem to remain stable (4). Successful actions in early childhood can positively influence the pattern of oral health throughout life, but poor habits during the first years of life hardly change in the future. Dental care for schoolchildren is usually based on interventional and curative actions, which impairs the development of public health proposals for organizing a comprehensive and universal oral health care policy considering the inclusion of children of zero to five years of age (5).

Analysis of socioeconomic and preventive factors is important to determine the proportion of children at highrisk for dental caries. The etiology of dental caries is multifactorial and leads to many interpretations of causality of prevalence changes in developed and developing countries over time. This variation in dental caries rates may be related to changes in dietary habits and oral hygiene, increased contact with fluorides, modifications in the oral ecology and/or biofilm virulence and changes in the oral protection mechanisms including the immune status $(6,7)$. As dietary and oral hygiene habits are established in the early childhood, the successful implementation of preventive and educational programs to promote oral health in infants and preschool children requires the involvement and motivation of parents, guardians and the whole family (8-10).

Dental professionals are increasingly working with school teachers as a task force in the preventive oral health programs. This interdisciplinary work has resulted in good practices as specific information is given to the population when the early child is still acquiring dietary and oral health habits. This may contribute to have a more aware and informed population about the importance of oral health prevention in the near future $(11,12)$.

The aim of this study was to investigate the impact of the implementation of a non-restorative health promotion program on dental caries activity in children enrolled in public childcare centers from the city of João Pessoa, PB, in the Northeastern region of Brazil.

\section{Methodology}

\section{Study design}

This was an interventional and longitudinal (12-month evaluation) study. The research project was approved by the Ethics and Research Committee of the Center of Health Sciences, Federal University of Paraíba (Protocol 60/02), with authorization from the City Department of Education.

The non-restorative health promotion program lasted 12 months with quarterly meetings, with a total of ten visits. Three child daycare centers were selected based on the geographic distribution in the city and the number of users. During this period, educational lectures were given to children and parents or guardians, including topics related to the importance of oral health, etiology and prevention of dental caries. The educational material included posters, flyers, videotapes, coloring drawings, macromodels and albums with illustrations. The clinical-preventive procedures were performed in accordance with the children age and included oral exam, oral hygiene and tooth brushing with gauze and application of topical fluoride gel with the use of a toothbrush.

\section{Sample selection}

All children enrolled in daycare centers in the city of João Pessoa, PB, in the Northeastern region of Brazil, were included in the study. Thus, the sample consisted originally of 328 children from 0 to 48 months of age from three nurseries. Of these, 109 children were transferred and not re-examined, totaling 219 children participating in the program that were divided into four groups according to the age criteria established: Group I: 0 to 12 months, Group II: 13 to 24 months, Group III: 25 to 36 months and Group IV: 37 to 48 months. Children underwent specific preventive procedures in accordance with the age group.

\section{Clinical examination and risk assessment}

The visual clinical examination was performed in the daycare centers under indirect natural light after prophylaxis (supervised tooth brushing) and with the aid of tongue depressor, mouth mirror, gauze and nebulizer to dry the tooth surface and facilitate the observation of white spots. The dmft index was based on the WHO criteria (13), and the dental caries activity criteria adopt the white spot index by Nyvad et al. (14). The same calibrated examiner performed the clinical examination of all children for $\mathrm{dmft}$ $(\mathrm{Kappa}=0.82)$ and white spot activity $(\mathrm{Kappa}=0.70)$. Children diagnosed with caries lesions in dentin were referred to a restorative treatment with a written communication to parents. The clinical examinations were conducted in two stages: initial (baseline) - before the quarterly actions of the program of oral health promotion, and after 12 months of the implementation of the program.

Variables related to the risk of caries were investigated by a structured interview: day and night oral hygiene habits (at least one brushing after the last meal), nursing, dietary 
items (milk with sugar, milk with dough and sugar, milk with dough without sugar and natural milk).

\section{Statistical analysis}

Data were analyzed by using the SPSS package (Statistical Packcage for Social Sciences, USA). The Mann-Whitney $\mathrm{U}$ test was used for comparison between groups due to the non-normality of data. A level of significance of $5 \%$ was defined a priori.

\section{Results}

Table 1 displays the descriptive statistics of the $\mathrm{dmft}$ values by age group and time of clinical examination during the oral health program. Most children in the sample $(\mathrm{N}=219)$ belonged to the group of children aged between 25 and 36 months $(n=71,32 \%)$, followed by the age groups between 13 and 24 months $(n=64,29 \%), 37$ and 48 months $(n=53$, $24 \%)$ and 0 to 12 months of age $(n=31,14 \%)$.

The parents of four out of 219 children refused to provide data on dietary and oral health habits. Results from the remaining 215 children in the sample showed that only 36 children (16\%) no longer used nursing bottle. Children aged between 25 and 36 months $(n=71)$ reported using nursing bottle with larger frequency than the other groups, but bottle feeding was reported until 48 months of age. The most common food given to the children was milk with dough and sugar $(n=106)$ in all age groups.
Night breastfeeding was more frequent in the age between 13 to 24 months $(n=21)$ and 25 to 36 months $(n=22)$, respectively. Table 2 shows that 148 children performed night oral hygiene (mean $\mathrm{dmft}=0.43$ ). However, 67 children who did not performed tooth brushing before bedtime had 1.10 mean dmft. Data showed a statistically significant association between caries and night oral hygiene $(P<0.01)$.

Regarding tooth brushing practice, 23 mothers performed oral hygiene of their children once a day, 115 mothers did it twice daily, 73 did it three times a day or more and 4 did not perform brushing. Tooth brushing practice was higher for children of 13 to 24 months and 25 to 36 months. The frequency of tooth brushing twice a day was the most used. Children who did not drink nursing bottle at night $(n=141)$ had a mean dmft of 0.33 , whereas children with nursing bottle feeding practice at night $(n=74)$ presented a mean $\mathrm{dmft}$ of 1.23 . There was a statistically significant association between the presence of caries and the use of nursing bottle at night (Table 2).

The groups of children aged from 13 to 24 months and from 25 to 36 months had the higher frequency of active white spot, with 71 and 64 children, respectively. Table 3 shows that the number of children without active white spot at the beginning of the program was lower than the number of children without active white spot at the final session after the last clinical examination. In all nurseries the number of children without active white spot increased after the program.
Table 1. Descriptive statistics (mean, SD) of the dmft values by age group and time of clinical examination during the oral health program $(\mathrm{N}=219)$.

Table 2. Initial dmft in relation to nocturnal oral hygiene and use of bottle feeding at night $(\mathrm{N}=215)$.

\begin{tabular}{lcccc}
\hline \multicolumn{1}{c}{ Age Group } & Visit 1 & Visit 2 & Visit 3 & Visit 4 \\
\hline O to 12 months & & & & \\
N & 31 & 31 & 31 & 31 \\
Mean dmft & 0.00 & 0.00 & 0.00 & 0.00 \\
SD & 0.00 & 0.00 & 0.00 & 0.00 \\
13 to 24 months & & & & \\
N & 64 & 64 & 64 & 64 \\
Mean dmft & 0.36 & 0.41 & 0.42 & 0.45 \\
SD & 1.04 & 1.16 & 1.22 & 1.36 \\
25 to 36 months & & & & \\
N & 71 & 71 & 71 & 71 \\
Mean dmft & 0.70 & 0.70 & 0.80 & 0.82 \\
SD & 1.26 & 1.26 & 1.47 & 1.51 \\
37 to 48 months & & & & \\
N & 53 & 53 & 53 & 53 \\
Mean dmft & 1.32 & 1.34 & 1.36 & 1.32 \\
SD & 1.92 & 1.94 & 1.97 & 1.94 \\
Total & & & & \\
N & 219 & 219 & 219 & 219 \\
Mean dmft & 0.65 & 0.66 & 0.71 & 0.72 \\
SD & 1.38 & 1.41 & 1.50 & 1.53 \\
\hline
\end{tabular}

\begin{tabular}{lcccc}
\hline & \multicolumn{2}{c}{ Nocturnal oral hygiene* } & \multicolumn{2}{c}{$\begin{array}{c}\text { Nocturnal use of } \\
\text { bottle feeding** }\end{array}$} \\
\cline { 2 - 5 } & Yes & No & Yes & No \\
\hline $\mathrm{N}$ & 148 & 67 & 74 & 141 \\
Mean dmft & 0.43 & 1.10 & 1.23 & 0.33 \\
Standard deviation & 1.08 & 1.78 & 1.84 & 0.91 \\
Standard error & 0.01 & 0.22 & 0.21 & 0.07 \\
\hline
\end{tabular}

* Mann-Whitney $U$ test; $z=-2.97 ; P<0.05$

** Mann-Whitney U test; $z=-4.11 ; P<0.05$ 
Table 3. Number of children without active white spot before and after the educational preventive program.

\begin{tabular}{cccc}
\hline $\begin{array}{c}\text { Daycare } \\
\text { nursery }\end{array}$ & $\begin{array}{c}\text { Initial } \\
\text { Examination }\end{array}$ & $\begin{array}{c}\text { Final } \\
\text { Examination }\end{array}$ & Difference \\
\hline A & 63 & 69 & +6 \\
B & 50 & 55 & +5 \\
C & 80 & 89 & +9 \\
Total & 193 & 213 & +20 \\
\hline
\end{tabular}

\section{Discussion}

The recent decline in the prevalence of dental caries observed in urban areas of Brazil is not geographically uniform and follows a polarization pattern. Caries is still frequent in some areas particularly in non-fluoridated Brazilian cities such as Joao Pessoa $(4,15)$. Nevertheless, few studies have investigated the risk factors associated with health promotion measures that are effective in controlling caries in early childhood (16). In this context, most measures of health promotion for this age group still need to be proved since many studies were done in adolescents (17). The later the intervention in preschool education aiming behavioral changes, the smaller the chances of success. In contrast, early lessons learned by young children are followed naturally (7-12).

The oral health promotion program developed for this study included the application of routine oral health procedures (supervised brushing with fluoride toothpaste) in preschoolers associated with a strong message of motivation, discipline at the times of oral hygiene and control of cariogenic foods. Data on the evolution of active white spots in Table 3 indicate indirectly that the program was effective. The use of posters, videotapes, macromodels, puppets and face painting drawings during this program positively involved the children and the education staff of all nurseries. These educational resources help to trigger the children's imagination, convey information in an easy language to understand and increase the child motivation to follow good practices in oral healthcare, allowing an active participation in the program (8-10). According to Hausen et al. (17), health promotion programs fail when there is not a mutual understanding between leaders (mothers, caregivers) and patients (children). The present preventive program yielded satisfactory results as the educational activities were widely appreciated by all children, mothers and nursery staff even after several sessions. From the standpoint of success in reducing dental caries activity, it was observed that the mean dmft was stable over the 12 months. For ethical reasons a control group was not included in the study, which would be important for the study design from the methodological point of view. On the other hand, studies with children from the same location show high caries activity (15). Thus, the program efficiency was interpreted as satisfactory oral health status by arresting or reversing carious processes, which can be actually observed as maintenance of the $\mathrm{dmft}$ mean values at the end of the program (Table 1).
It is noteworthy that a considerable number of children began the program with some caries activity. In addition, all children were from low-income families, and their parents had little education, i.e., a situation that hindered the program's direction and goals of care. For Tuono et al. (18), different circumstances can affect oral health, from individual characteristics related to lifestyle to geographic and socioeconomic access to material and social resources. In this context, the program was developed in a hostile environment where etiologic factors and determinants for dental caries development were reported in previous epidemiological studies in the city of Joao Pessoa $(15,19)$, in other cities from the Northeast of Brazil (20) and in other parts of the country $(16,21)$.

The children with up to 12 months of age at the baseline of the program had null dmft and remained caries-free at the end of the study. This initial evaluation demonstrates that the early attention given to children with parental involvement is important for the effectiveness of the program for dental caries control. Children who entered the program at the age from 13 to 24 months presented an average $\mathrm{dmft}$ higher than or equal to 0.3 , i.e., they showed presence of dental caries at baseline with a sequential increase for the following age groups due to the accumulation of caries activity in previous years.

Important factors contributing to the early onset of dental caries are the early colonization of Streptococcus mutans, introduction of bottle feeding with sweetened liquids, combined with early weaning, other forms of high frequency of sucrose exposure, use of bottle feeding at night with prolonged period of time in the mouth, frequency and quality of toothbrushing, amount of dental biofilm and low rates of utilization of oral health services (22).

Silva et al. (19) observed that the prevalence of caries in 2-6 year-old children was high in João Pessoa, and the frequency of tooth brushing and presence of active white spot were risk indicators in that population. In the present study, dental caries was related to age and bottle feeding, often overnight. The lack of oral hygiene at night was a major factor for the development of white spot carious lesions. Data indicate that the lack of oral hygiene at night requires more attention from parents or guardians who supervises the child tooth brushing.

The final results after 12 months suggest a positive contribution of fluoride presence to arrest white spots (Table 3 ). The partial or complete removal of etiologic factors, such as dental biofilm and cariogenic diet, are also important and inter-related with behavioral changes, motivation and active participation in the program (23). For Figueiredo et al. (24), a dental program centered on a model of health promotion is able to positively change the pattern of dental caries activity in preschool children, even with the inherent difficulties of this age, making inevitable the direct participation of third parties. Fraiz and Walter (25) stated that one way to prevent and control dental caries is the specific attention to oral heath promotion in the first year of life. In this sense, an educational oral health promotion program to implement 
healthy habits will require fewer resources than the measures to modify deleterious habits later and correct their effects (17).

In summary, this educational program was effective to maintain the short-term oral health as caries-free children remained in this condition for 12 months, until the end of the program, and there was a reduction of active white spots. The main risk factors for dental caries were the lack of nocturnal oral hygiene and use of bottle-feeding. Thus, this study suggests that the chances of maintaining good oral health are improved if oral health promotion is implemented in early childhood.

\section{References}

1. Massoni ACLT, Forte FDS, Sampaio FC. Percepção de pais e responsáveis sobre promoção de saúde bucal. Rev Odontol UNESP 2005;34:193-7.

2. Morano Jr M, Mialhe FL. A importância da professora na promoção de saúde bucal dos escolares. Rev Odontol Unicid 2008; 20:19-22.

3. Pine CM, Adair PM, Petersen PE, Douglass C, Burnside G, Nicoll $A D$ et al. Developing explanatory models of health inequalities in childhood dental caries. Community Dent Health 2004;21:86-95.

4. Ministério da Saúde (Brasil). Secretaria de Atenção à Saúde. Projeto SB Brasil 2003. Condições de saúde bucal da população brasileira 2002-2003: resultados principais. Brasília: Ministério da Saúde; 2004.

5. Freire MCM. Prevalência de cárie e fatores socio-econômicos em pré- escolares: revisão da literatura. Rev bras odontol saúde coletiva 2000; 1:43-9.

6. Moura C, Cavalcanti AL, Bezerra PKM. Dental caries prevalence in 12-year-old schoolchildren in the city of Campina Grande, Paraíba, Brazil: a socioeconomic approach. Rev Odonto Ciênc 2008;23:256-62

7. Moura LdeF, Moura MS, Toledo OA. Dental caries in children that participated in a dental program providing mother and child care. J Appl Oral Sci 2006; 14:53-60.

8. Bonow MLM, Casalli JF. Avaliação de um programa de promoção de saúde bucal para crianças. JBP: J Bras Odontopediatr Odontol Bebê 2002;5:390-4.

9. Guimarães MS, Zuanon ACC, Spolidório DMP, Bernardo WLC, Campos JADB. Atividade de cárie na primeira infância fatalidade ou transmissibilidade? Ciênc Odontol Bras 2004;7:45-51.

10. Chibinski ACR, Wambier DS. Protocolo de promoção de saúde bucal para a criança portadora de cárie de estabelecimento precoce. Pesqui bras odontopediatria clín integr 2005;5:281-90.

11. Aquilante AG, Almeida BS, Castro RFM, Xavier CRG, Peres SHCS, Bastos JRM. A importância da educação em saúde bucal para préescolares. Rev Odontol UNESP 2003;32:39-45.

12. Alves MU, Volschan BCG, Haas NAT. Educação em saúde bucal: sensibilização dos pais de crianças atendidas na clínica integrada de duas Universidades privadas. Pesqui Bras Odontopediatria Clín Integr 2004;4:47-51.

13. World Health Organization. Oral health surveys: basic methods. 4. ed. Geneva: World Health Organization; 1997.
14. Nyvad B, Machiulskiene V, Baelum V. Reliability of a new caries diagnostic system differentiating between active and inactive caries lesions. Caries Res 1999;33:252-60.

15. Lima JMC, Silva ACB, Forte FDS, Sampaio FC. Risco e prevenção à cárie dentária: avaliação de um programa preventivo aplicado em uma clínica infantil. RGO 2008;56:355-9.

16. Antunes JLF, Peres MA, Mello TRC. Determinantes individuais e contextuais da necessidade de tratamento odontológico na dentição decídua no Brasil. Ciên Saúde Coletiva 2006;1 1:79-87.

17. Hausen $H$, Seppa L, Poutanen R, Niinimaa A, Lahti S, Kärkkäinen S, Pietilä I. Noninvaise control of dental caries in children with active initial lesions. A randomized clinical trial. Caries Res 2007 ; 41:384-91.

18. Tuon ACLF, Lacerda JT, Traebert J. Prevalência de cárie em escolares da zona rural de Jacinto Machado, SC, Brasil. Pesqui Bras Odontopediatria Clín Integr 2007;7:277-84.

19. Silva JS, Silva FDSCM, Forte FDS, Sampaio FC. Prevalência de cárie e indicadores de risco em crianças de 2 a 6 anos na Clínica de Odontologia Preventiva - UFPB. Rev Odonto Ciênc 2006; 21:17-21.

20. Feitosa S, Colares V. Prevalência de cárie dentária em pré-escolares da rede pública de Recife, Pernambuco, Brasil, aos quatro anos de idade. Cad Saúde Pública 2004;20:604-9.

21. Bönecker M. Cárie dentária: um enfoque epidemiológico. In: Bönecker M, Sheihan A. Promovendo a saúde bucal na infância e adolescência: conhecimentos e práticas. São Paulo: Santos; 2004. p.13-28.

22. Hallet KB, O'rourke PK. Early childhood caries and feeding practice. Community Dent Health 2002; 19:237-42.

23. Tolvanen M, Lahti S, Poutanen R, Seppä L, Pohjola V, Hausen $H$. Changes in children's oral health-related behavior, knowledge and attitudes during a 3.4-yr randomized clinical trial and oral healthpromotion program. Eur J Oral Sci 2009;1 17:390-7.

24. Figueiredo MC, Rosito DB, Michel JA. Avaliação de 07 anos de um Programa Odontológico para Bebês com Bases Educativa, Preventiva e Restauradora. JBP: J Bras Odontopediatr Odontol Bebê 1998; 1:33-40.

25. Fraiz FC, Walter LRF. O comportamento infantil durante a higiene bucal domiciliar e alguns fatores associados à cárie. JBP: J Bras Odontopediatr Odontol Bebê 2001 ;4:398-404. 